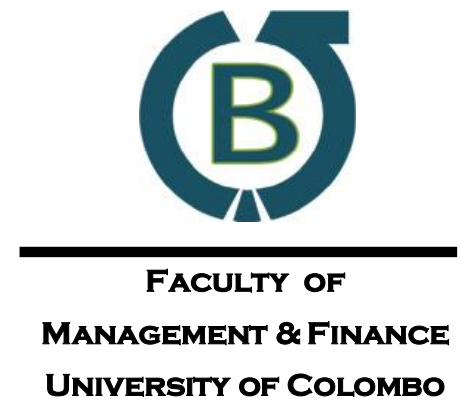

UNIVERSITY OF COLOMBO
Colombo

Business

Journal

Vol. 04, No. 01, June 2013
International Journal

of Theory \& Practice

\title{
The Impact of Innovative-Supportive Culture on Employee Performance in Software Development Companies of Sri Lanka
}

\author{
M. Srikantharajah ${ }^{a}$, R. Senathiraja ${ }^{b}$ \\ ${ }^{a}$ University of Wales (UK) \\ ${ }^{b}$ Department of Management and Organisation Studies, University of Colombo, Sri Lanka
}

\begin{abstract}
The main purpose of this research is to investigate the impact of innovative culture on employee performance at software companies of Sri Lanka. It explores the degree of impact on each factor of innovative culture on employee performance. The research hypothesizes that in software companies, innovative culture has a positive relationship on the employee performance and determinants of innovative culture. This empirical study draws upon a survey from software developers, business analyst, project managers and others who are directly involved in projects from the software development companies. Correlation and Multiple regression analyses proved that the impact innovative culture had on employee performance is strongly positive. Dimensions of innovative culture also had a positive impact on employee performance except the dimension 'trust' which did not have a statistically significant impact. This research study emphasises on the importance of fostering innovation as a way of business philosophy through the organisational culture which results in having a sustainable competitive advantage. It is not limited to the product but extends to employees too. The knowledge created has contributed to the business environment of Sri Lanka in relation to best organisational culture practices. Finally recommendations are given to practically implement some of the cultural practices that are lacking in Sri Lankan software companies.
\end{abstract}

Keywords: Innovative culture, Employee performance, Organisational culture, Sri Lankan software companies, Innovation

\footnotetext{
${ }^{a}$ Corresponding author: laxumy@gmail.com
} 


\section{Introduction}

Innovative culture is a type of culture that can be seen in many organisations who empower employees. Many articles have been published (Anthony, 2004; Armson, 2008; Daniels, 2011; Hess, 2012) giving value to the culture that encourages innovation which is termed as innovative culture. This millennial concept has manifested due to high competition in the marketplace.

Sri Lanka's Information Technology (IT) sector has grown immensely over the past decade. Sub sectors including software development, IT infrastructure, hardware equipment, web hosting, web designing and mobile application development form the entire industry. Recently government of Sri Lanka had made initiatives (ICTA, 2012) to increase the investment flow to further expand the industry. In future, there will be much more new firms emerging and the demand for employment in the sector is expected to grow. IT firms not only cater the needs of local companies but also focusing on international companies especially through BPO (Business Process Outsourcing). Sri Lankan companies are compelled to adhere to the global standards. As many of the Asian countries are flooding up to capture international market, Sri Lanka should improve its quality in all aspects of its product and processes.

Cooper \& Kleinschmidt stated (2010) that innovative culture is one of the critical success factors for new product development. Jassawalla \& Sashittal (2002) identified organisations with highly innovation-supportive culture which encourage taking initiative, creativity and risk-taking among its members.

Human Resource concept bestowed a value to the human potential and showed the importance of taking care of the most valuable asset in the company (Armstrong, 2008). Companies understand the mutual benefit between them and employees who working for them. At present, high profile companies are hunting for high calibre employees which require the organisations to be attractive enough to the potential candidates. Many companies make efforts to be one of the 'best places to work' which creates goodwill among young professionals, attract and retain talent more easily (Gibson, 2012). This has resulted in building up the culture in organisations which binds the people together while fostering creative thinking and facilitates innovation within the company. This way companies are able to stand ahead in the competitive marketplace while taking care of their employees. Today as we all aware, IT Companies need to thrive everyday which requires new ideas very often than ever before in history. Ideas are not generated by machines. For ideas, creative minds are essential. Companies are in search of these potential candidates who can take the company and its value to the next level.

It is an explicit fact that innovative culture is aspired by most of the organisation to improve its market position (Hall \&Vopel, 1997) through encouraging individuals to perform well. According to Stathakopoulos (1998), individual performance should not be measured using organisational performance. Revenue of the company, profit per annum, market share increase; all such indicators show how much organisation performs in a quantitative manner. How much an employee contributes to this figure is not realistic to measure, this is because above mentioned elements can be the result of market conditions and strategy formulation of the company.

Culture is a qualitative aspect of an organisation and its impact on employee performance in terms of their achievement of individual objectives is quite fair. Individual objectives will include what is 
expected by the organisation from that employee (Mindtools, 2012). Organisational culture is about the norms and behaviour seen in the members of organisation that has been cultivated throughout a period. Hence organisation culture determines the commitment of an employee (Naicker, 2008) towards his tasks and behaviour. All the above argument is considered while measuring employee performance. Therefore, the researchers had a question whether innovative culture influences the employee performance in software companies in Sri Lanka.

\section{Objectives of the Study}

1. To explore the relationships between innovative culture and employee performance in Sri Lankan software companies

2. To identify the level of each factors of an innovative culture influence employee performance at Sri Lankan software companies

\section{Scope of the Study}

This research is restricted to Sri Lankan software and IT enabled services industry. According to Sri Lanka Association of Software and Services Companies (SLASSCOM) there are companies that are performing extremely well in Sri Lankan software and IT enabled services industry. These organisations are selected for this research. Data is collected from employees consisting of project managers, software developers, quality assurance executives, business analysts and designers who are directly involved in software development projects from each organisation. Innovative culture is considered as the independent variable and employee performance is considered as the dependant variable. An extensive literature review is carried out to find suitable dimensions for both independent and dependant variables. In addition, researchers found and added new dimensions of innovative culture, based on preliminary interviews.

\section{Literature Review}

\subsection{Culture, Organisational Culture and Innovative Culture}

Anderson and Taylor (2007) explain culture as 'a complex system of meaning and behaviour that defines the way of life for a given group or society which includes beliefs, values, knowledge, art, morals, laws, customs, habits, language and dress.' Culture determines the way of thinking of the members, hence an individual tend to show or behave in line with the culture he is associated from society. This creates a sense of belongingness, give direction on how to do things and instruct how to think and make decisions in different circumstances. These primary societal values, beliefs and practices are absorbed in an individual who carries the same to the organisation, yet organisational culture is not a replica of societal culture, if that is the case all the organisation would have had the same culture (Sinha, 2009).

According to Haybyrne (2002) organisational culture is defined as values, beliefs, and norms that are exhibited in the way that people in the organisation accomplish their work, relate to one another, and solve the problems that confront them on a daily basis. It coordinates members' behaviour by letting them understand and accept the values and beliefs about how things are done in the organisation (Fernando, 2010). Organisational culture is the expression of the characteristic of the organisation which can be communicated by symbolism, emotions, conduct, meaning behind the words, work setting and even through a piece of art (Martins \& Terblanche, 2003). 
According to Cameron and Quinn (2011) that organisation can have four main different types of culture where all the other combination of culture can fit. These include creative/ adhocracy culture which depicts a dynamic, entrepreneurial and creative work environment that encourages thinking differently where innovation and risk taking will be embraced by employees and leaders. Innovative culture is a new concept that has been fostered by many companies especially in past few decades. It is the culture where creative thinking is central to organisational values, assumptions and actions (Deloitte, 2005). Main difference between other organisational culture and innovative culture is, latter will encourage creative thinking and innovation while keeping the human values at optimum.

Anthony (2004) argues that innovation is all about inventing things; but has forgotten about the inescapable need to do things in better ways. Innovation was once an end results where only process related or product related innovation was considered, but now due to the high degree of competition, innovation has to be a part of organisation in the form of its culture. Tidd, Bessant, \& Pavitt (2005) suggest that innovative culture is where innovation can thrive. Artefacts of culture are structure and processes. Hence, by modifying at the level of these artefacts through reinforcing behavioural patterns creativity can be inhibited followed by successful implementations of innovations.

Hussain \& Illyas (2011) argued that innovative culture enables an organisation to react to the dynamic changes in the market, to anticipate future challenges and opportunities. This will result in sustainable competitive advantage. Ahmed (1998) also emphasised on importance of creating appropriate culture and climate that is conducive for human communities to strive towards innovation which ultimately results in sustainable competitive advantage'. Adding further to his point, Sutton (2001) states that innovative culture is seen in an organisation when its employees are encouraged to experiment their ideas and to implement innovations together with their managers. All the arguments of researchers reveal that innovative culture is not only about producing innovative output that are favourable, but also about constantly keeping positive attitude of, thinking out of the box among employees of the organisation.

Armson (2008) stated in her research findings that the key to create a culture of innovation is emergent learning which means unstructured, non-organised learning, engaged in by individuals and/or by groups, that questions the status quo of the organisation. Daniels (2010) argues that innovation should be a strategic priority of the company which encourage change and a visionary leadership is necessary to execute it. Based on her survey (Daniels, 2011) with companies of Boston Consulting Group's top 100 most Innovative Companies list, it was found that there are six different cultural characteristics were showcased by innovative workplaces that include; context rich, creating customer value, confidence building, curious workforce, challenging and collaboration. Dombrowski, Kim, Desouza, Braganza, Papagari, Baloh, \& Jha (2007) have discovered eight elements of innovative culture based on their exploratory multiple case study research with 30 American and European companies who have the track records of integrating business partners in their innovation processes. They are innovative mission and vision statements, democratic communication, safe spaces, flexibility, collaboration, boundary spanning, incentives and leadership. In the research done by Swedish researcher Goran Ekwall with 22 managers from software development companies and recent graduates, he has mentioned nine characteristics that are favourable for organisations to employ innovative culture. They are; challenge and involvement, freedom, trust and openness, idea time, playfulness/humour, conflict, idea support, debates and risk-taking (Ekwall, Britz, \& Lauer, 2000). 
Dombrowski et al. (2007) suggested based on their research on elements that affects innovative culture, democratic communication can happen with encouraging participation at all levels. This also can take a problem cantered approach, where people who are interested in and involved in finding solutions for problems may be free of restrictions.

Leigh Thompson (HBR, 2012) states success of the endeavours such as making a new product or implementing a customer service initiative or creative solution that eases work process depends on the effectiveness of collaboration. Daniels (2011) argues that in earlier times innovations are possible by one person such as Einstein and Edison, but in the present era of technology with so many complicated processes, innovation is not possible without team work. She has confirmed that by citing a North-Western University study of 19.9 million scientific papers and 2.1 million patents that showed when more participants are involved in innovation efforts better results were produced (Daniels, 2011). Adler, Hechscher, \& Prusak (2011) have mentioned in their research article, people tend to contribute more when they have trust among their team members. It comes from how much each member believes that other member is willing and able to further shared mission of the team. This kind of trust has to be present among team members, not having the fear that someone might steal his idea and say it is theirs. This point is further strengthened by Ekwall et al. (2000) who have mentioned in their research paper of 'Best and worst climate for creativity', when trust is missing people are suspicious and tend to guard each other, hide their plans and ideas. But when trust is there they are able to communicate easily and count on each other for professional and personal support. They are not reluctant to give credit for the co-worker who deserves it.

Daniels (2011) reveals in her 'six C' model for creating innovative culture, that curious individuals question the existing methods or output and tries to find answer through creative ideas. Therefore curiosity is also one of the important trigger for creative thinking. Workplace arrangement have important role in stimulating creativity in an organisation. This can be seen many global organisations such as Google, Apple and many other software development organisations. Their workspaces give abundant places for group discussion and meetings. Cubicles are discouraged to avoid close communication and lack of transparency. They also have facilities such as for entertainment to get a break between jobs as they believe it will freshen up people and they could focus more after such recreational activity. During interviews it was noticed that organisations such as WSO2, E-marketing and CAMMs solutions in Colombo seem to facilitate spaces with such energising activities or more open infrastructure. Research done by a furniture organisation called 'Steelcase' found that organisations who plan workspaces to support collaborative work processes and work styles will be the most likely to produce larger-than-life innovations (Steelcase, 2004). Fyard \& Weeks (2011) has done surveys over the 12 years based on effects of design on interaction and found spaces that facilitate proximity, privacy and permission which facilitate interactions results in trust, co-operation and innovation.

Dombrowski et al. (2007) found through his research that flexibility is present in organisation which allows employees to work beyond the normal protocols and procedures. This can include working hours, workstations, usual procedures of getting thing done etc. For a company with strong flexibility, shifting to a problem-centred innovative culture may help to increase democratic, lateral communication and strengthen the likelihood of innovations being heard and experimented with. $\mathrm{He}$ found that world-renowned creative organisation $3 \mathrm{M}$ provided its employees flexibility to work on the idea right from conceptualization to successful commercialization. Flexible options are not only a 
powerful attracting high-calibre people; but also helps retain them by meeting the needs of a "new and different" pool of talent. For example working hours are usually 8.30-5, but when organisations that do not worry about the time people came for work, but worry about whether they have achieved the goal or not, motivates employees especially who are in software development.

Employee development in soft skills was found by researcher through the interviews with prominent software development organisations in Colombo. According to Sri Lankan scenario, most of the employers felt that societal-culture here is such that it makes employees more reserved, selfcentred than people-oriented. They also agreed that experienced professionals tend to stick to the old norms that have been worked for them for years and willing to change for the good of organisation and themselves. This has resulted in organisations to move to the trend of recruiting freshers from universities and colleges and training them accordingly that will suit their organisational culture. Many organisations focus mentoring and workshops from this aspect, addition to technical training. They feel the importance of soft skills training for local people as they understood it affects work performance to a great extent.

Dombrowski et al. (2007) state that innovations usually require the organisation to change in some way, hence leaders who are not necessarily from top management will act as change agents and motivate employees time to time to keep up the positive attitude. All big innovators had a few things in common: big aspirations, a flexible definition of their businesses, and a habit of experimentation; but the overall organisational cultures differed dramatically because management styles were strikingly different. Ibarra \& Hanson (2011) also mentioned that leadership that encourage innovation need to be different such as encouraging participation from diverse groups, being able to accept feedback, questioning status quo and speed decisions.

\subsection{Employee Performance}

Most of the literature point out employee performance as the outcome of the efforts made by employees in respective industries (Christen, Iyer, \& Soberman, 2006). According to Sonnentag \& Fresse (2001), following methods are ways to improve job performance; goal setting, feedback interventions, behaviour modification, improvement of action process, training and job design. But Christen et al. (2006) argue that effort should be distinguished from performance, as effort does not define the outcomes which show if the performance increased or not. Stathakopoulas (1998) defined employee performance actions, decision, motivations and effective behaviour as measurements for. He also stresses on the point how it can defer from organisational perspective. In context employees following was considered; carrying out company policies, attempting to meet performance objectives, managerial performance in solving day to day problems and monitoring competitive behaviour (Stathakopoulas, 1998). According to Rehman (2009) employee performance has two dimensions i.e., working performance and monetary performance. Working performance was defined in terms of employee retention, achievement of the goals of organisation, employee productivity and objectivity of performance evaluation system. Monetary performance was measured in terms of monetary and non-monetary benefits of the employees.

According to Debra \& James (2006) organisational citizenship is one of the dimensions in employee performance. This will measure the qualitative aspect of the individual performance. In previous item scale used by Rehman (2009), measure the performance aspects that directly influence 
the job objectives of an employee as an individual. But organisational citizenship behaviour emphasizes on collective achievement. This aspect is more suitable for finding the relationship between innovative culture and employee performance. Lievens \& Anseel (2004) stated that Organisational citizenship behaviour explains the social and psychological contribution of an employee to the follow members and organisation. He has included dimension such as helping behaviour, sportsmanship and civic virtue. Performance increases only when the employees who rightly fit to organisational culture are being recruited. In other way employees who are struggling adapt them for the organisational culture may find it difficult perform as organisation expects. McShane\& Von Glinow (2005) have explained that organisational culture act as a bond among the employees of the organisation and makes them feel integral part of organisation. This will motivate employees to be committed to the work and be able to perform task with the sense of responsibility. Organisational culture also allows effective communication among the members, so that they are able to figure out the task easily. Because employees share a common goal in a sound organisational culture, they are able to corporate with each other and understand them more. All these factors contribute to the increased employee performance. The Table 1 and 2 explain the dimensions of innovative culture and its relationship with the employee performance.

Table 1: Attributes of Innovative Culture

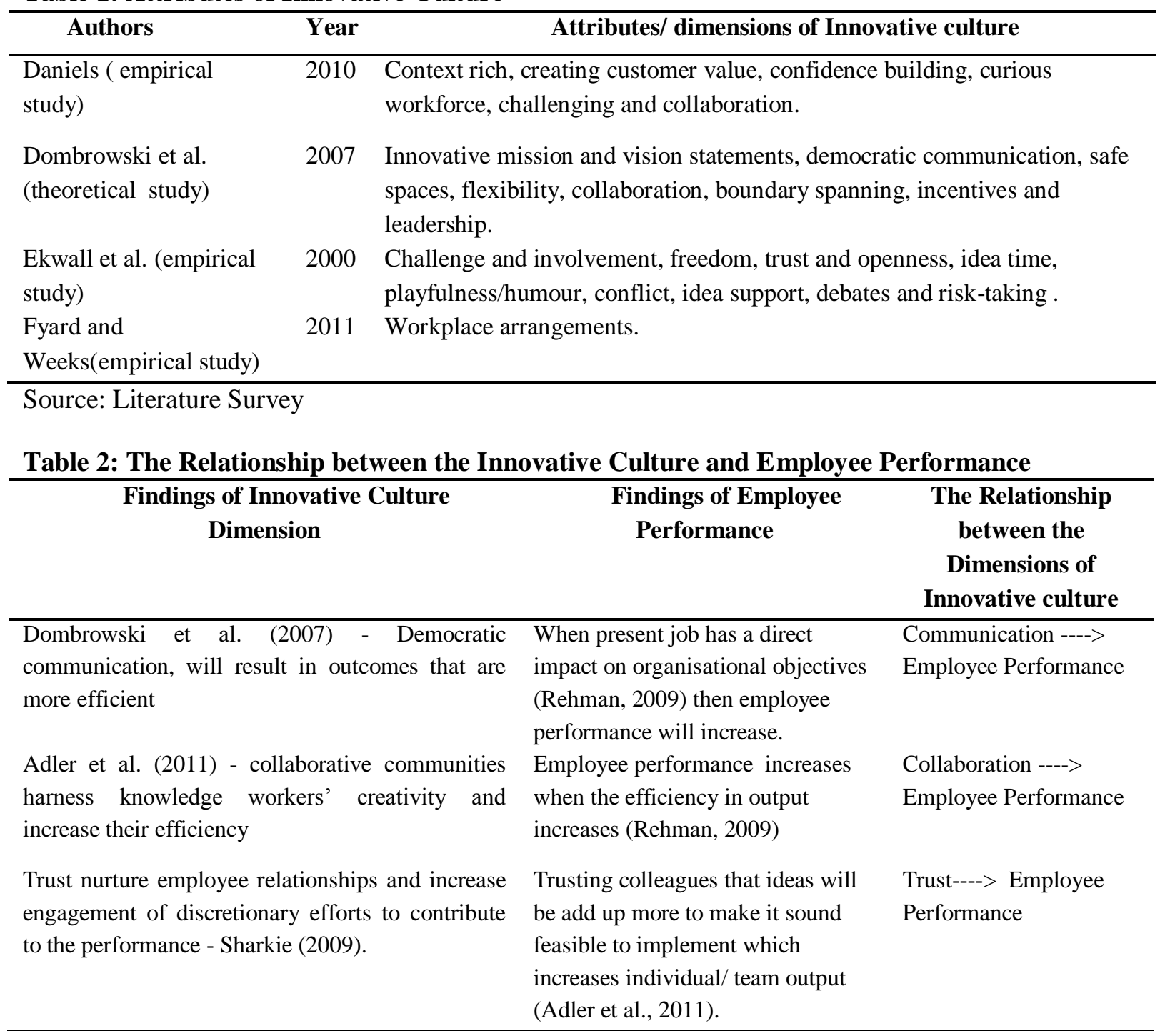




\begin{tabular}{|c|c|c|}
\hline Findings of Innovative Culture Dimension & $\begin{array}{l}\text { Findings of Employee } \\
\text { Performance }\end{array}$ & $\begin{array}{l}\text { The Relationship } \\
\text { between the } \\
\text { Dimensions of } \\
\text { Innovative culture }\end{array}$ \\
\hline $\begin{array}{l}\text { Workplace that encouraged and supported } \\
\text { brainstorming, increased free exchange of ideas, } \\
\text { networks that encourage collaboration, } \\
\text { effectiveness of work processes (Steelcase, 2004). }\end{array}$ & $\begin{array}{l}\text { Employee performance increases } \\
\text { when the effectiveness increases } \\
\text { (Rehman, 2009). }\end{array}$ & $\begin{array}{l}\text { Workplace } \\
\text { arrangement ----> } \\
\text { Employee Performance }\end{array}$ \\
\hline $\begin{array}{l}\text { Flexibility has helped millennium generation to be } \\
\text { more productive with increased outcomes - } \\
\text { Hewlett (2011). }\end{array}$ & $\begin{array}{l}\text { Individual outcomes are consistent } \\
\text { with organisational objectives - } \\
\text { employee performance (Rehman, } \\
\text { 2009). }\end{array}$ & $\begin{array}{l}\text { Flexibility----> } \\
\text { Employee Performance }\end{array}$ \\
\hline $\begin{array}{l}\text { Noor \& Dola (2012) have also agreed that } \\
\text { productivity increases after training and } \\
\text { development is given on employees. }\end{array}$ & $\begin{array}{l}\text { Individual outcomes are } \\
\text { consistent with organisational } \\
\text { objectives -employee performance } \\
\text { (Rehman, 2009). }\end{array}$ & $\begin{array}{l}\text { Employee development - } \\
--->\text { Employee } \\
\text { Performance }\end{array}$ \\
\hline $\begin{array}{l}\text { Leadership which constantly strive innovation } \\
\text { helps every employee to be successful in their job } \\
\text { which result in increase in performance (Ibarra } \\
\text { \&Hanson, 2011). }\end{array}$ & $\begin{array}{l}\text { Employee performance increases } \\
\text { when the efficiency in output } \\
\text { increases (Rehman, 2009). }\end{array}$ & $\begin{array}{l}\text { Leadership ----> } \\
\text { Employee Performance }\end{array}$ \\
\hline
\end{tabular}

Source: Literature Survey

\section{Research Methodology}

\subsection{Conceptual Model and Hypothesis Development}

The conceptual model explains the relationship between the dimensions of innovative culture and employee performance. Innovative culture is considered as independent variable and employee performance considered as dependent variable. Independent variable, innovative culture was recently developed construct and has been studied empirically by researchers as mentioned in literature review. Dependent variable, employee performance tested very often throughout business empirical researchers. These two constructs are seldom associated in research, instead researchers have quoted that performance will increase if innovative culture is present. Therefore, innovative culture as an independent variable and employee performance as dependent variable will enable to find out the influence of innovative culture in employee performance. Eight dimension of innovative culture mentioned in framework are based on literature review. Dimensions developed by researcher, employee development in soft skills are to the local software development industry. How each dimension affects employee performance is justified in below section. From the literature and theories related to this study help to develop the following hypothesises.

Dombrowskiet al. (2007) state Democratic communication, an idea from follow member which can be commented positively or suggesting improvements will result in outcomes that are more efficient. When present job has a direct impact on organisational objectives (Rehman, 2009) that is being innovative, then employee performance will increase.

HO- Positive association does not exist between the democratic communication and employee performance

H1- Positive association does exist between the democratic communication and employee performance 


\section{Figure 1: Conceptual Model}

$\underline{\text { Independent variables of }}$

$\underline{\text { Innovative culture }}$

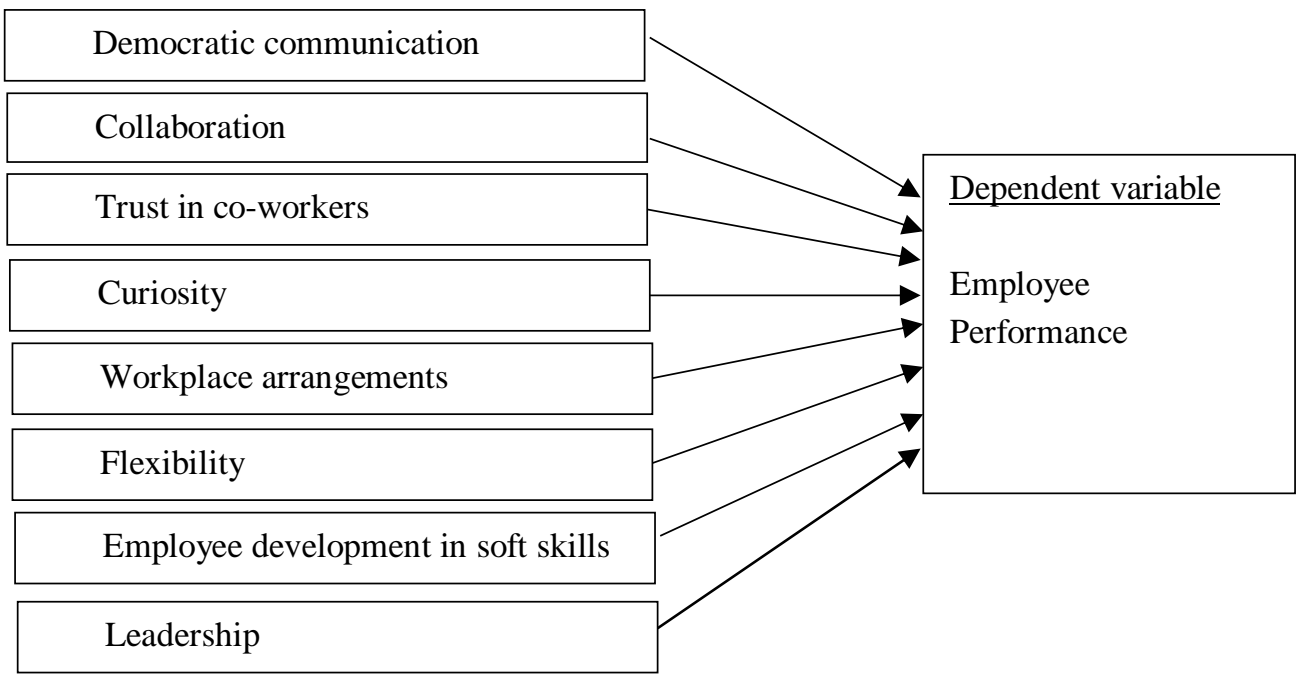

Source: Developed by the researchers

Adler et al. (2011) also have mentioned that collaborative communities harness knowledge workers' creativity in a flexible but also highly manageable fashion, in their research study based on innovation and efficiency. They stressed on how workers performance can increase due to collaboration. Ibarra \& Hansen (2011) have found through the interviews with top-performing companies in US that people from diverse communities in a team, tend to produce unique and diverge ideas.

HO- Positive association does not exist between the curiosity and employee performance

H2- Positive association does exist between the collaboration and employee performance

Sharkie (2009) has insisted on the importance of trust in encouraging employee performance. He found that how trust can nurture employee relationships and in turn results in engagement of discretionary efforts to contribute to the organisational performance. When an employee has a great new idea he first tend to share it with his close colleague, trusting that colleague might mould it or add up more to make it sound feasible to implement (Adler et al., 2011). When there is trust in organisation one will show extra-role behaviour which increases one's performance.

HO- Positive association does not exist between the trust and employee performance

H3- Positive association does exist between the trust and employee performance

Ekwall et al. (2000) agree that employees tend to commit time on tasks other than their own assignment, when they voluntarily come up with questions and ideas out of curiosity. This way more and more ideas are generated which result in a pool of ideas to choose the best out of it. This curiosity will make employees to work long hours to see the outcomes of their project.

These outcomes are consistent with organisational objectives which is one of attribute of employee performance.

HO- Positive association does not exist between the curiosity and employee performance

H4- Positive association does exist between the curiosity and employee performance 
When a design firm created a workplace that encouraged and supported brainstorming, peer critiques, and the free exchange of ideas, innovation measures jumped to $15 \%$; networks that encourage collaboration are $14 \%$ healthier; effectiveness of work processes is up 37\%, (Steelcase, 2004). The research was based 40 different organisations around the world and studies show that teams given visual display devices, easy access to storage, and the right work surfaces, accomplish tasks twice as fast. This shows that workplace arrangements have an impact in employee performance.

HO- Positive association does not exist between the workplace arrangements and employee performance

H5- Positive association does exist between the workplace arrangements and employee performance

Hewlett (2011), President of Centre for Innovations says 'Flex work, including the option of telecommuting, offers employers numerous low-cost, high-return advantages. The most obvious payoff of flexibility: Employees can concentrate without being interrupted by phone calls, meetings, and other workplace distractions'. This has helped millennium generation to be more productive. Because each person will work accordingly with his nature, some maybe productive during late night and some may be productive in early morning or during day time. This will help them to increase their job performance.

HO- Positive association does not exist between the flexibility and employee performance

H6- Positive association does exist between the flexibility and employee performance

Employee development in soft skills is an important aspect in training and development. In Sri Lanka most of the software development graduates are from State universities who has mastered their technical skills exceptionally but failed to see any opportunities to develop their soft skills. Hence many organisations focus more on this aspect while understanding the importance soft skills development has on their employees' performance. Noor \& Dola (2012) have also agreed that productivity increases after training and development is given on employees.

HO- Positive association does not exist between the Employee development in soft skills and employee performance

H7- Positive association does exist between the Employee development in soft skills and employee performance

When leader is encouraging members to be creative and come up with ideas as much as possible irrespective of what diverse community they are in, will motivate employees with the sense of inclusion. Without only encouraging only top performers or experienced people or any other discrimination based on diversity, leadership which constantly strive innovation helps every employee to be successful in their career. Mentoring support is often seen informally among leaders who genuinely care for job performance of employees which result in increase in organisational performance (Ibarra and Hanson, 2011).

HO- Leadership that supports innovative behaviour does not positively enhance the employee performance

H8- Leadership that supports innovative behaviour positively enhances the employee performance

Above independent dimensions explain the construct, innovative culture, hence innovative culture and employee performance is tested using below hypothesis.

HO - Dimensions of innovative culture will not impact on employee performance

H9-Dimensions of innovative culture will impact on employee performance 


\subsection{Operationalisation of the Conceptual Model}

The Table 3 depicts the operationalisation of the variables of the conceptual model.

Table 3: Operationalisation of the Conceptual Model

\begin{tabular}{|c|c|c|c|c|}
\hline & Dimensions & Indicators & Code & Measurement \\
\hline \multirow[t]{17}{*}{$\begin{array}{l}\text { Innovative } \\
\text { culture }\end{array}$} & Communication & $\begin{array}{l}\text { Voluntary participation of all } \\
\text { employees }\end{array}$ & Com1 & 5 category \\
\hline & & $\begin{array}{l}\text { Organisation encourage informal } \\
\text { employee networks }\end{array}$ & Com2 & $\begin{array}{l}\text { Likert scale, } \\
\text { where }\end{array}$ \\
\hline & & $\begin{array}{l}\text { Accepting ideas without role } \\
\text { restrictions }\end{array}$ & Com3 & $1=$ Strongly \\
\hline & & $\begin{array}{l}\text { No barriers of waiting for approvals to } \\
\text { communicate job related matter with } \\
\text { member in another team }\end{array}$ & Com4 & Disagree, \\
\hline & & $\begin{array}{l}\text { Employees are able to speak up any } \\
\text { issues without worrying about job }\end{array}$ & Com5 & $2=$ Disagree \\
\hline & & security and continuity & & $3=$ neutral, \\
\hline & Collaboration & Employees prefer working in teams & Coll1 & \\
\hline & & $\begin{array}{l}\text { New ideas were generated more during } \\
\text { teamwork than in solitude }\end{array}$ & Coll2 & 4= Agree \\
\hline & & $\begin{array}{l}\text { Teams are mostly consist of diverse } \\
\text { communities (gender, ethnic, } \\
\text { experience, culture, language) }\end{array}$ & Coll3 & $\begin{array}{l}\text { and } \\
5 \text { = Strongly }\end{array}$ \\
\hline & & $\begin{array}{l}\text { Employees are motivated by a } \\
\text { collective mission than individual } \\
\text { achievement }\end{array}$ & Coll4 & Agree \\
\hline & & Employees feel harmony in the group & Coll5 & \\
\hline & & $\begin{array}{l}\text { Employees are empathy towards team } \\
\text { members (care about each other) }\end{array}$ & Coll6 & \\
\hline & Trust in co-workers & $\begin{array}{l}\text { Employees are truthful and honest in } \\
\text { their opinions }\end{array}$ & Tru1 & \\
\hline & & $\begin{array}{l}\text { Employees do not take any action that } \\
\text { is not expected by others that may put } \\
\text { other employees in trouble }\end{array}$ & Tru2 & \\
\hline & & $\begin{array}{l}\text { Able to make good judgment in } \\
\text { interpersonal relationships }\end{array}$ & Tru3 & \\
\hline & & $\begin{array}{l}\text { Employees are reflecting consistent } \\
\text { behaviour in dealing with others }\end{array}$ & Tru4 & \\
\hline & & $\begin{array}{l}\text { Employees do not have the threat that } \\
\text { others might copy their idea, so easily } \\
\text { share their ideas with co-workers }\end{array}$ & Tru5 & \\
\hline
\end{tabular}




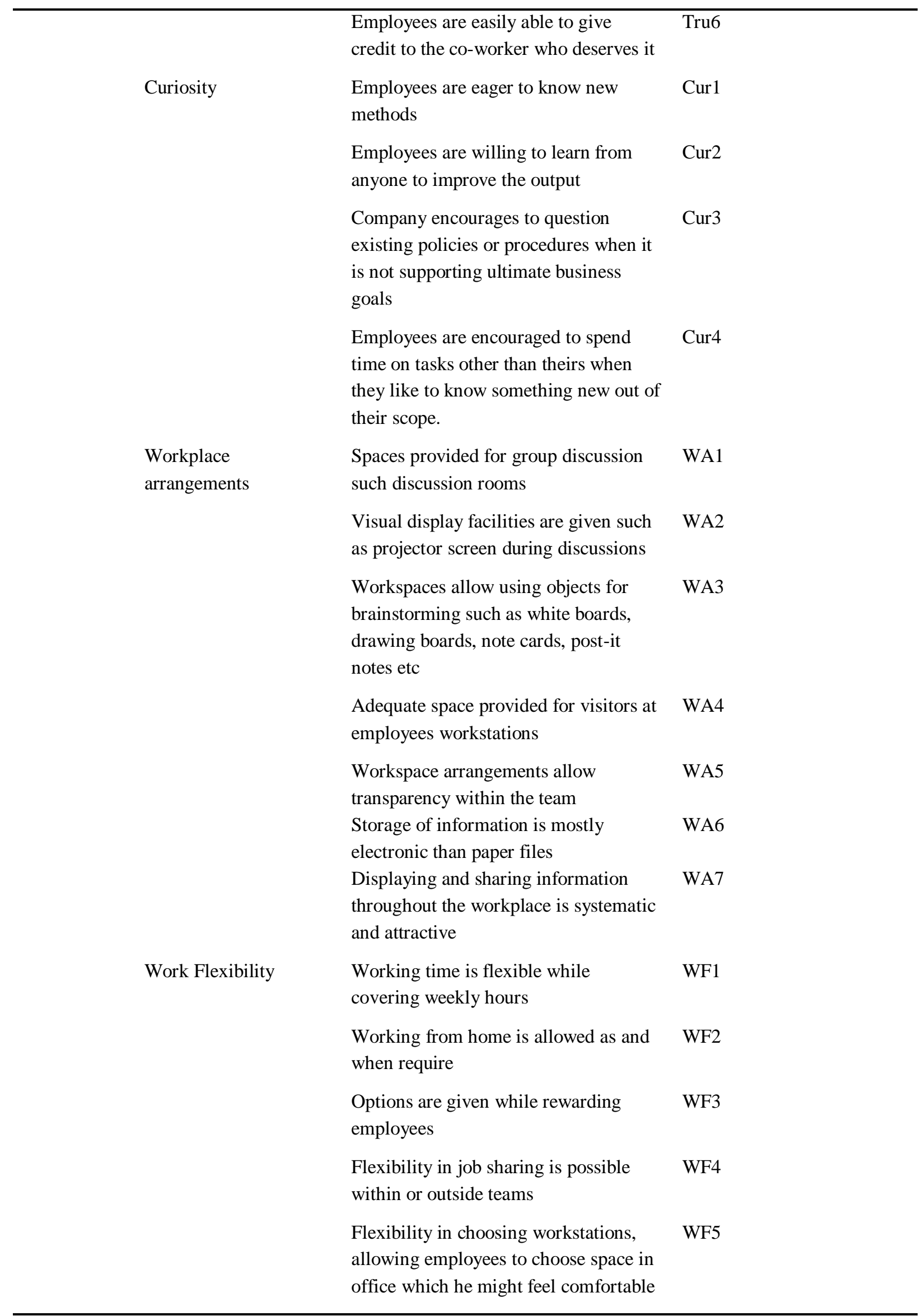




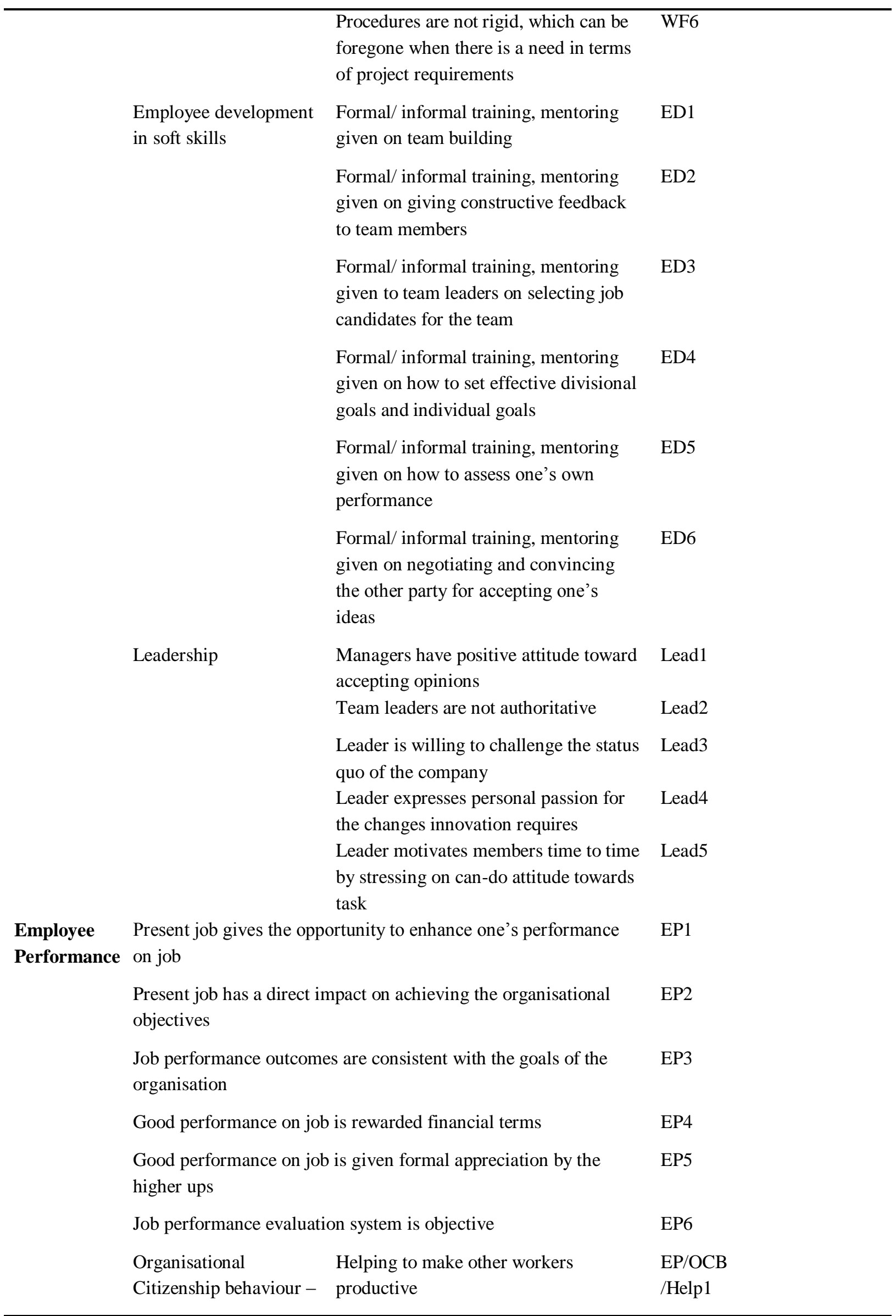




\begin{tabular}{|c|c|c|}
\hline helpfulness & $\begin{array}{l}\text { Helping colleagues who are with heavy } \\
\text { workload }\end{array}$ & $\begin{array}{l}\text { EP/OCB } \\
\text { /Help2 }\end{array}$ \\
\hline & Helping others who have been absent & $\begin{array}{l}\text { EP/OCB } \\
\text { /Help3 }\end{array}$ \\
\hline \multirow{4}{*}{$\begin{array}{l}\text { Organisational } \\
\text { Citizenship behaviour - } \\
\text { Sportsmanship }\end{array}$} & Complains a lot about trivial matters & $\begin{array}{l}\mathrm{EP} / \mathrm{OCB} \\
/ \mathrm{Sp} 1\end{array}$ \\
\hline & $\begin{array}{l}\text { Always finds fault with what the } \\
\text { organisation is doing }\end{array}$ & $\begin{array}{l}\mathrm{EP} / \mathrm{OCB} \\
/ \mathrm{Sp} 2\end{array}$ \\
\hline & $\begin{array}{l}\text { Expresses resentment with any changes } \\
\text { introduced }\end{array}$ & $\begin{array}{l}\mathrm{EP} / \mathrm{OCB} \\
\text { /Sp3 }\end{array}$ \\
\hline & $\begin{array}{l}\text { Does not complain about work } \\
\text { assignments }\end{array}$ & $\begin{array}{l}\mathrm{EP} / \mathrm{OCB} \\
\text { /Sp4 }\end{array}$ \\
\hline $\begin{array}{l}\text { Organisational } \\
\text { Citizenship behaviour - } \\
\text { Civic nature }\end{array}$ & $\begin{array}{l}\text { Stays informed about developments in } \\
\text { the company } \\
\text { Pays no attention to announcements, } \\
\text { messages or printed material that } \\
\text { provide information about the company }\end{array}$ & $\begin{array}{l}\text { EP/OCB } \\
/ \text { Civ1 } \\
\text { EP/OCB } \\
/ \text { Civ1 }\end{array}$ \\
\hline
\end{tabular}

Source: Developed by the researchers

\subsection{Research Sample}

IT industry is very much wide which comprises of sectors such as hardware, networking and software. It is not appropriate to select IT industry as whole because the level of innovation is perceived different in these sectors (IBM, 2010). Software development sector involves more of creating, designing and idea generation that requires much creativity and innovative approach. Since the objective of the research is to measure the relationship between innovative culture and employee performance, a sector that will match within the IT industry was chosen. Member list of Sri Lanka Association of Software and Services is used as target population. Total of 129 software development companies were listed as members. Companies which had revenue more than US \$ 1000000 were selected subsequently. It amounted to 33 companies. All 33 companies were contacted for the survey. However 21 companies refused to participate in the study. The main reasons were; in some companies their company policy does not allow sharing information with third parties and rest of them were busy with on-going projects. As a result the sample got reduced to 12 companies. All software developers, business analyst, project managers and other who are directly involved in projects were distributed with questionnaires. Out of 180 questionnaires provided altogether only 99 questionnaires were received resulting in 55\% response rate. It is understood that the software industry is volatile and busiest industry. Since most of the companies have asked not to mention the company name, they were not revealed.

Sampling method followed was cluster sampling. It is a method of probabilistic sampling method where target population is divided into meaningful clusters and all the elements in the chosen clusters is taken for the study (Sekeran, 2003). Data is collected though survey method by distributing questionnaires. To analyse the findings from main sample, tests such as correlation and regression were carried out. Findings were not merely based on face values/ observed values, but recommended 
statistical tests were used to check if they are significant. Correlation and linear regression is used to find the impact of innovative culture on employee performance. Multiple regression analysis is used to find the impact of each dimension of independent variable on dependant variable.

\section{Data Analysis}

\subsection{Reliability and Validity}

The major measurement properties validated here are validity and reliability. According to Nunnaly's standard as restated by Malhotra (2004), Chronbach's alpha should be more than 0.7. It is the average of all split-half coefficients resulting from different ways of splitting the scale items. After carrying out reliability test with the remaining indicators, it was found that all the dimensions are reliable except 4 dimensions which fall into $0.6-0.7$. Though these are not highly reliable, it is reasonable as Malhotra stated that (2003) generally values below 0.6 are unsatisfactory. For employee performance Chronbach was 0.79 whereas Rehman (2009) obtained Chronbach of 0.77 for employee performance in different setting.

Convergent validity was established by performing factor analysis. According Malhotra (2010), factor loading should be ideally more than 0.7 which means $50 \%$ of the dimension is explained by the indicators selected, since $0.7^{2}=50$. He also mentioned that minimum standard of 0.6 can be set (Malhotra, 2010). Furthermore, KMO and Bartlett's test of sphericity were carried out. KMO helps to identify the sampling adequacy where the observed correlation is compared with partial correlation. Value more than 0.5 indicates that correlation is high among the indicators. Bartlete test of sphericity is used to find if the variables are correlated in the population (Malhotra, 2011). It is based on the chisquare transformation of the correlation matrix. If the chi-square is significant at or below 0.05, appropriateness of the factor analysis is confirmed. As a part of Convergent validity, Composite Reliability and Average Variance Extracted (AVE) should be calculated. Composite reliability is defined as the total amount of true score variance in relation to the total score variance (Malhotra, 2011). If the tests produce a value greater than 0.7 items are considered valid.

\subsection{Relationship between Innovative Culture and Employee Performance in Sri Lankan Software Development Industry}

Table 4: Correlation Analysis

\begin{tabular}{lll}
\hline & & Innovative culture \\
\hline Employee Performance & Pearson Correlation & $.970^{* *}$ \\
& Sig. (2-tailed) & .000 \\
& $\mathrm{~N}$ & 99 \\
\hline
\end{tabular}

Source: Survey Data

To examine whether there is an association between the degree of innovative culture and employee performance is high in 49 of the sample. 40 of the sample have moderate innovative culture and among them employee performance is also moderate in 38 of the sample. Only 3 of the sample have low degree of innovative culture and among them employee performance also low in 2 of the sample. 
To examine whether there is an association between the degree of innovative culture and employee performance Pearson's Correlation test was also carried out taking mean values of independent and dependant variables. The results of the test are given in Table 4,r value is 0.970 and significant at alpha $=0.000$ level suggesting that the statistically significant association exist between innovative culture and employee performance. As per the sample selected that is high revenue companies in which innovative culture has already been implemented, it is possible to get a high figure such as 0.97 for the total mean. Question items have been properly operationalised and tested through validity and reliability. Hence, this result although it is high it can be accepted. Also it has to be noted that the result is symmetrical relationship, where the 0.97 could mean that employee performance increases when innovative culture dimension increases or innovative culture dimension increases due to employee performance increase. Consequently, correlation merely shows the symmetrical values and does not identify the association between the independent and dependant variable. Therefore regression analysis is carried out by taking innovative culture as independent variable and performance as the dependant variable. Results of the regression analysis are given in Figure 2.

Figure 2: Results of Regression Analysis

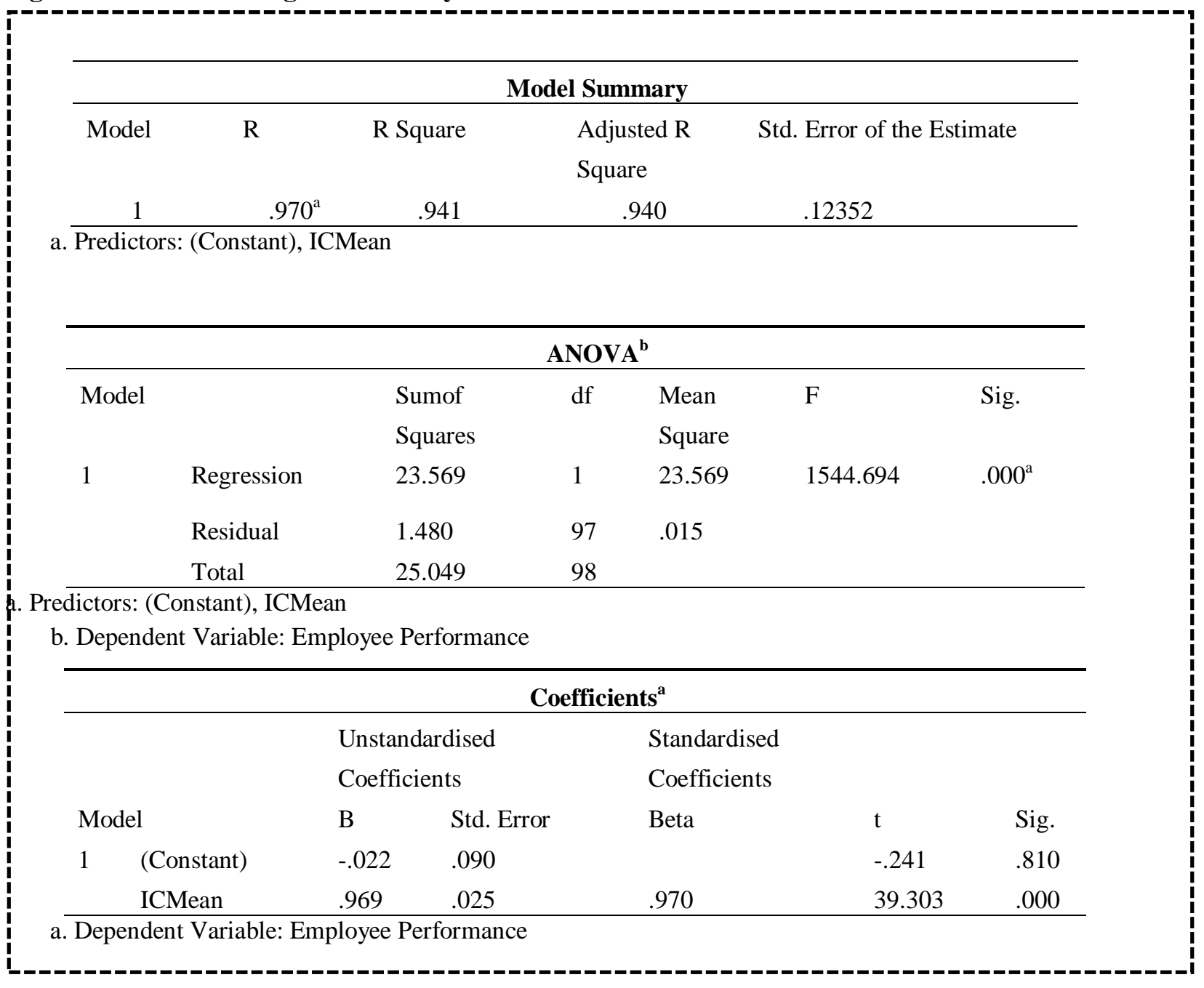

Source: Survey Data 
The results show that adjusted $\mathrm{R}$ (Coefficient of determination) is 0.94 . Respective $\mathrm{F}$ value is 1544, significant at 0.01 levels, which shows strength of relationship is significant. As per Malhotra (2011), if the relationship between independent and dependant variable is significant, it is meaningful to predict the values of dependant variable based on the values of independent variable and to estimate prediction accuracy. Therefore using the above values relationship of innovative culture and employee performance of Sri Lankan software industry can be predicted. According to Figure 2, Beta coefficient (Standardised regression coefficient) of innovative culture is 0.97 which shows the amount of change in the dependant variable employee performance. Further, t value (39.303) is significant at $\alpha=0.000$ suggesting the change in employee performance due to innovative culture is statistically significant. Therefore innovative culture has a strong positive influence on employee performance of software development organisations.

Hypothesis number one and related null hypothesis were tested based on the results of the simple regression analysis given in Figure 2. The results of the test show a statistically significant strong positive association between innovative culture and employee performance. Therefore, null hypothesis is rejected. Alternative hypothesis is confirmed.

HO - Positive association does not exist between innovative culture and employee performance

H1- Positive association does exist between innovative culture and employee performance

\subsection{The extent of the dimensions of innovative culture influence on employee performance in}

\section{Sri Lankan software companies}

To find out the extent to which the factors of innovative culture influence the employee performance. To examine the influence of each factor of innovative culture on employee performance correlation analysis was performed. Results are given in the Table 5.

Table 5: Correlation Analysis with Each Dimension of Innovative Culture and Employee Performance

\begin{tabular}{|c|c|c|c|c|c|c|c|c|}
\hline & 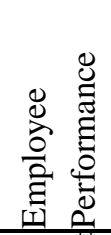 & 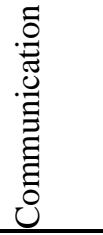 & 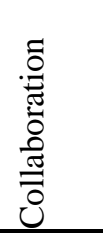 & $\stackrel{\vec{E}}{E}$ & $\begin{array}{l}\overrightarrow{0} \\
0 \\
0 \\
0 \\
0\end{array}$ & 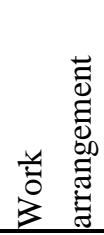 & 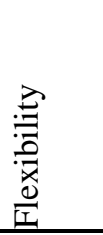 & 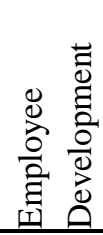 \\
\hline Communication & $.830^{* *}$ & & & & & & & \\
\hline Collaboration & $.822^{* *}$ & $.880^{* *}$ & & & & & & \\
\hline Trust & $.808^{* *}$ & $.818^{* *}$ & $.847^{* *}$ & & & & & \\
\hline Curiosity & $.654^{* *}$ & $.521^{* *}$ & $.425^{* *}$ & $.544^{* *}$ & & & & \\
\hline $\begin{array}{l}\text { Work } \\
\text { arrangement }\end{array}$ & $.815^{* *}$ & $.777^{* *}$ & $.731^{* *}$ & $.721^{* *}$ & $.503^{* *}$ & & & \\
\hline Flexibility & $.723^{* *}$ & $.670^{* *}$ & $.786^{* *}$ & $.806^{* *}$ & $.359^{* *}$ & $.642^{* *}$ & & \\
\hline $\begin{array}{l}\text { Employee } \\
\text { Development }\end{array}$ & $.880^{* *}$ & $.564^{* *}$ & $.550^{* *}$ & $.586^{* *}$ & $.606^{* *}$ & $.591^{* *}$ & $.470^{* *}$ & \\
\hline Leadership & $.823^{* *}$ & $.562^{* *}$ & $.507^{* *}$ & $.456^{* *}$ & $.591^{* *}$ & $.544^{* *}$ & $.277^{* *}$ & $.915^{* *}$ \\
\hline
\end{tabular}

Source: Survey Data 
Table 5 explains the Pearson correlation $\mathrm{r}$ values of each dimension of innovative culture with Employee Performance. All the values are above 0.6 and significant at 0.001 level, which show each dimension, is highly correlated with employee performance. Highest among them is employee development which seems to influence employee performance more than the other factors. Communication, leadership, collaboration, workplace arrangements and trust influence the employee performance respectively and have values more than 0.8 . Work flexibility is lower than the other criterion. Curiosity results are the lowest still with reasonable correlation with employee performance.

Figure 3: Multiple Regression Analysis of Innovative Culture Dimensions and Employee Performance

\begin{tabular}{|c|c|c|c|c|c|c|c|}
\hline \multicolumn{8}{|c|}{ Model Summary } \\
\hline \multirow{2}{*}{$\begin{array}{r}\text { Model } \\
1 \\
\end{array}$} & \multirow{2}{*}{$\begin{array}{r}\mathrm{R} \\
991^{\mathrm{a}} \\
\end{array}$} & \multirow{2}{*}{$\begin{array}{l}\text { R Square } \\
.983 \\
\end{array}$} & \multirow{2}{*}{\multicolumn{2}{|c|}{$\begin{array}{l}\text { Adjusted R Square } \\
.981\end{array}$}} & \multicolumn{3}{|c|}{ Std. Error of the Estimate } \\
\hline & & & & & \multicolumn{3}{|c|}{.06922} \\
\hline \multicolumn{8}{|c|}{$\begin{array}{l}\text { a. Predictors: (Constant), LeadMean, WFMean, CurMean, WAMean, ComMean, TrMean, ColMean, EDMean } \\
\text { b. Dependent Variable: EmployeePerformance }\end{array}$} \\
\hline \multicolumn{8}{|c|}{ ANOVA } \\
\hline \multirow{4}{*}{$\begin{array}{c}\text { Model } \\
1\end{array}$} & & & Sum of Squares & Df & Mean Square & $\mathrm{F}$ & Sig. \\
\hline & Regression & & 24.618 & 8 & 3.077 & 642.157 & $.000^{\mathrm{a}}$ \\
\hline & Residual & & 431 & 90 & .005 & & \\
\hline & Total & & 25.049 & 98 & & & \\
\hline
\end{tabular}

a. Predictors: (Constant), LeadMean, WFMean, CurMean, WAMean, ComMean, TrMean, ColMean, EDMean

b. Dependent Variable: EmployeePerformance

\begin{tabular}{|c|c|c|c|c|c|c|}
\hline \multicolumn{7}{|c|}{ Coefficients $^{\mathrm{a}}$} \\
\hline \multirow[t]{3}{*}{ Model } & & \multirow{2}{*}{\multicolumn{2}{|c|}{ Unstandardised Coefficients }} & \multirow{2}{*}{\multicolumn{3}{|c|}{$\begin{array}{l}\text { Standardised } \\
\text { Coefficients }\end{array}$}} \\
\hline & & & & & & \\
\hline & & B & Std. Error & Beta & $\mathrm{t}$ & Sig. \\
\hline \multirow[t]{9}{*}{1} & (Constant) & -.074 & .058 & & -1.270 & .207 \\
\hline & ComMean & .086 & .024 & .128 & 3.636 & .000 \\
\hline & ColMean & .066 & .030 & .084 & 2.179 & .032 \\
\hline & TrMean & .020 & .031 & .022 & .640 & .524 \\
\hline & CurMean & .046 & .016 & .057 & 2.941 & .004 \\
\hline & WAMean & .127 & .020 & .152 & 6.405 & .000 \\
\hline & WFMean & .181 & .023 & .239 & 7.960 & .000 \\
\hline & EDMean & .244 & .047 & .248 & 5.233 & .000 \\
\hline & LeadMean & .251 & .041 & .289 & 6.047 & .000 \\
\hline \multicolumn{7}{|c|}{ a. Dependent Variable: Employee Performance } \\
\hline
\end{tabular}

Source: Survey Data 
However Correlation analysis does not distinguish between independent variable and dependant variable. Therefore multiple regression analysis is carried out, results of which is given in Figure 3. As per regression analysis 98.3 percent of the dependant variable, employee performance is explained by the dimensions of innovative culture. But Trust has significant level above 0.05 which means its variations are not significant at $95 \%$ confidence level.

Hypothesis number two and related null hypothesis were tested based on the results of the multiple regression analysis given in Figure 3. The results of the test show a statistically significant strong positive association between communication and employee performance. Therefore, null hypothesis is rejected. Alternative hypothesis $H 2$ is confirmed.

Hypothesis number three and related null hypothesis were tested based on the results of the multiple regression analysis given in Figure 3. The results of the test show a statistically significant strong positive association between collaboration and employee performance. Therefore, null hypothesis is rejected. Alternative hypothesis $H 3$ is confirmed.

Hypothesis number four and related null hypothesis were tested based on the results of the multiple regression analysis given in Figure 3. The results of the test show there is no statistically significant strong positive association between trust and employee performance. Therefore, null hypothesis is accepted. Alternative hypothesis $H 4$ is not confirmed.

Hypothesis number five and related null hypothesis were tested based on the results of the multiple regression analysis given in Figure 3. The results of the test show a statistically significant strong positive association between curiosity and employee performance. Therefore, null hypothesis is rejected. Alternative hypothesis $H 5$ is confirmed.

Hypothesis number six and related null hypothesis were tested based on the results of the multiple regression analysis given in Figure 3. The results of the test show a statistically significant strong positive association between workplace arrangement and employee performance. Therefore, null hypothesis is rejected. Alternative hypothesis $H 6$ is confirmed.

Hypothesis number seven and related null hypothesis were tested based on the results of the multiple regression analysis given in Figure 3. The results of the test show a statistically significant strong positive association between work flexibility and employee performance. Therefore, null hypothesis is rejected. Alternative hypothesis $H 7$ is confirmed.

Hypothesis number eight and related null hypothesis were tested based on the results of the multiple regression analysis given in Figure 3. The results of the test show a statistically significant strong positive association between Employee development in soft skills and employee performance. Therefore, null hypothesis is rejected. Alternative hypothesis $H 8$ is confirmed.

Hypothesis number nine and related null hypothesis were tested based on the results of the multiple regression analysis given in Figure 3. The results of the test show a statistically significant strong positive association between leadership and employee performance. Therefore, null hypothesis is rejected. Alternative hypothesis $H 9$ is confirmed. 


\subsection{Discussion}

The rationale of this paper is to answer the fundamental question that arises as to whether innovative culture at software development companies being an instrumental for increasing their employee performance. Findings revealed there is a strong association between the two concepts. In order to answer this question cross tabulation, correlation and regression were carried out. Through cross tabulation it was noticed that most of the respondents who had high innovative culture also shared their employee performance is high. In order to explore further, how strongly two variables are related, correlation was performed. Findings showed that innovative culture and employee performance are highly correlated. It was similar to the findings of Gunawardena\& Carte (2007) who have found innovative practices are highly correlated with employee performance. Finally linear regression analysis was carried out to find how much change occurs in employee performance due to the change in innovative culture, and results showed employee performance change drastically due to the change in innovative culture. Findings revealed the similarity with of Dombrovoski et al. (2007) who mentioned superior performance is noticed through innovative culture practices in organisations.

In order to find out the extent of influence of each factor of innovative culture has on employee performance, correlation was performed and findings revealed that each of dimensions of innovative culture is strongly correlated to employee performance. Employee development was highly correlated with employee performance, which is similar to the findings of Armson (2008) who emphasised on learning and development in terms of being innovative. Furthermore, multiple regression analysis was performed to see the comparative influence on employee performance. Since it shows the comparative value, multiple regression best explains the change in employee performance in term of each of eight dimensions take in this study. Findings revealed that each of them has a positive influence on employee performance. It was found leadership has more influence than the employee development. This is going in line with what Dombrovoski et al. (2007) found, who revealed successful innovations need champions who can manage innovation from ideas to successful commercialisation. Hence, the objective to find each factor's influence on employee performance also revealed.

When testing the hypothesis developed based on variables explained in the framework, it was found hypothesis related to trust has to be rejected. Findings revealed that trust did not have a significant relationship with employee performance in Sri Lankan software companies. Though Sri Lankans demonstrate collective behaviour in family context, being able to trust their family members, at workplace they tend to show that trust do not increase their performance. Though Sri Lankan culture is more collective than individualistic, at workplace people try to be individualistic due to the competitiveness. This may be the reason for the findings that showed trust did not have any significant relationship with employee performance.

The main objective of this research was to examine the relationship between innovative culture and employee performance in the software industry of Sri Lanka. Accordingly, several sub objectives were formed and accomplished as mentioned in Section 6. H1; there is a relationship between innovative culture and employee performance, is accepted through performing tests such as correlation and regression. As one of the objective is to find to what extent each factor of innovative culture has influence on employee performance, hypothesis was formed for each dimensions; communication, collaboration, trust, curiosity, workplace arrangements, work flexibility, employee development and leadership. Though correlation matrix showed high Pearson correlation values, 
multiple regression analysis showed not all dimensions shows significant relationship. Association of dimension 'Trust' with employee performance is not statistically significant; therefore $\mathrm{H} 4$ is rejected. All the other dimensions showed association that is statistically significant; hence $\mathrm{H} 2, \mathrm{H} 3, \mathrm{H} 5, \mathrm{H} 6, \mathrm{H} 7$, $\mathrm{H} 8$ and $\mathrm{H} 9$ are accepted.

\section{Conclusion}

The research problem of the study is to identify the impact of innovative culture on employee performance at Sri Lankan software companies. This study explored two main research themes. First, it identified the association between innovative culture and employee performance. Second, it unearthed the impact of dimensions of innovative culture on employee performance. Innovative culture had a strong positive relationship with employee performance. Factors of innovative culture that are derived from literature and factors suggested by researcher are tested using the hypothesis. Results of hypothesis testing revealed that dimensions of innovative culture; communication, collaboration, curiosity, workplace arrangements, work flexibility, employee development and leadership had positive impact on employee performance. Trust did not have a significant impact on employee performance. This research has incorporated the determinants of innovative culture which is an emerging concept in the field of organisational behaviour. Studies have been conducted related to innovative culture during past few years. Since this concept is very volatile, the dimensions can change according to the time period and context. Hence the variable 'employee development' added by the researcher is an additional dimension to be considered within the local context. Further, the finding that innovative culture has a strong positive impact on employee performance is the new contribution to the existing literature on organisational culture. Findings related the dimensions of innovative culture that communication, collaboration, curiosity, workplace arrangements and work flexibility are having a significant impact on employee performance and trust is not having a significant impact gives the additional knowledge about innovative culture in terms of Sri Lankan context. This will help the organisational behaviour practitioners to form change strategies in terms of organisational culture modifications.

Further this research emphasises on the importance of fostering innovation as a way of business philosophy through the organisational culture. This will result in having a sustainable competitive advantage not just in terms of product but also in terms of employees. This idea is strengthened through the research findings. Therefore this will trigger the companies that did not realise innovation can be fostered through culture. The knowledge created through this research has contributed to the business context of Sri Lanka in terms of best organisational culture practices.

\section{Limitations of the Research}

The research study was carried out for software development industry in Sri Lanka. Target population was 220 employees from software development companies and questionnaires were distributed accordingly. Due to the busy schedule of software developers and others who are involved in projects, only 99 questionnaires were collected as valid questionnaires with maximum effort by the researcher. Therefore the findings were from only 12 companies that represent the target population of 140 firms. Only high performing companies (more than annual revenue of US\$ 1000 000) were selected assuming that they should be innovative in order to encompass competitive advantage that results in more customers and high revenue. This helps to find out the extent of the impact that innovative culture has on employee performance. More objective values such as collecting 
remuneration were not possible as the companies are reluctant to reveal them to the third parties. Hence, employee performance measurement is limited to suit the practical difficulties. It should also be noted that all the companies cater for international market. As a result the IT industry is further narrowed down to software development. This study represents only software development industry where conclusions have drawn. Further, research findings may vary in different sectors within the industry. Therefore only software development sector was considered for this study leaving out sectors such as hardware product companies, network management companies or Business Process Outsourcing sector. Companies who were reluctant to participate revealed that third parties were not allowed to collect data unless otherwise it is a research organisation or a consulting firm. Hence, there were many difficulties faced in collecting data, but high importance was given to the sample derived through probabilistic sampling. Moreover, it has to be noted that though maximum consideration was given to follow ideal research methodology but there might be deviations due to knowledge gaps.

\section{Directions for Future Research}

Many determinants of innovative culture were found through literature survey. However, due to the capacity of the researcher and time limit only 8 dimensions were included. In future, dimensions such as challenging tasks (Daniels, 2010), risk taking, idea support and dynamism (Ekwall et al. 2000) can be included while studying about innovative culture. This research was confined to Sri Lankan software industry. Different industry may produce totally different results. Industries such as fast moving consumer goods, telecommunication, hotels and textile can depict a different extent of impact on employee performance due to innovative culture. Therefore it is fruitful to examine the same constructs in different industries. Innovative culture was taken as independent variable and employee performance as a dependant variable. Moderating variable that could explain the impact was not taken into consideration. This can be considered in future research. Variables such as employee commitment or employee satisfaction can have a moderating effect that leads to employee performance change due to innovative culture are the examples.

\section{References}

Adler, P., Hechscher, C., \&Prusak, L. (2011).Building a collaborative enterprise. Harvard Business Review South Asia, 86-87.

Ahmed, P.K. (1998). Culture and climate for innovation. European Journal of Innovation Management, 1(1), 30-43.

Anderson, M. L. \& Taylor, H. F. (2007).Sociology: Understanding a Diverse Society. (4 ${ }^{\text {th }}$ ed.). Cengage Learning.

Anthony, B. (2004). Supporting an innovative culture. Lee Engineering Management, 14 (5), 28-32.

Armson,G. (2008, June). How Innovative is your culture. Paper presented at European Applied

Business Research Conference, Salzburg, Austria.

Armstrong, M. (2008).Strategic Human Resource Management: A Guide to Action. Kogan Page.

Bennett, M.L. (2011). Flexibility- The Business Case. Asheville NC:ML Bennet Consulting LLC Publishing.

Cameron, K.S., \& Quinn, R.E. (2011).Diagnosing and Changing Organisational Culture: Based on

The Competing Values Framework. Oxford: John Wiley \& Sons, Ltd.

Christen, M., Iyer, G., \& Soberman, D. (2006). Job satisfaction, job performance and effort; are examination using the agency theory. Journal of Marketing, 70, 137-150. 
Cooper, R., \&Klein Schmidt, E. J. (2010).Success Factors for New-Product Development.Oxford: John Wiley \& Sons, Ltd.

Daniels, S. (2010). Innovative culture: it's a leadership responsibility. Leadership Excellence, 27 (1), 15.

Daniels, S. (2011).The "Six C's" Model for Building a Culture of Innovation. Chief Executive

Magazine. RetrievedJune 10, 2012,from<http://chiefexecutive.net/the-aeoesix-c-model-for building-aculture-of-innovation>.

Debra, L. N.,\& James, C. Q. (2006).Organisational behaviour (5 ${ }^{\text {th }}$ ed.). Thomson Corporation: South-Western, USA.

Deloitte (2005).Fostering Innovative Culture.Retrieved March10, 2012, from< http://www.deloitte.com >.

Dombrowski, C., Kim, J.Y., Desouza, K.C., Braganza, A., Papagari, S., Baloh, P., \&Jha, S. (2007).Elements of Innovative Cultures. Knowledge and Process Management, 14(3), 190-202.

Ekwall, G., Britz, A., \& Lauer, K.J. (2000). Perceptions of the best and worst climate of creativity. Creativity Research Journal, 13(2), 171-182.

Fyard, A.L., \& Weeks, J. (2011, July). Who moved my cube?. Harvard Business Review South Asia, 93-100.

Fernando, V. (2010).Impact of Corporate Culture on Supply Chain Orientation in Manufacturing

Gibson, L. (2012).The 2012 Best Workplaces in Europe Revealed. Retrieved June 10, 2012,from<http://greatplacetowork.lk/publications-and-events/blogs-and-news/671-the-2012best-workplaces-in-europe-revealed.

Gunawardena, A.D.D., \& Carte, T. (2007).Gaining competitive advantage through innovation in the information technology sector. Sri Lankan Journal of Management, 12(3 \&4), 44-66.

Hall, B. H., \&Vopel, K. (1997).Innovation, Market Share, and Market Value.RetrievedJune10, 2012, from < http://elsa.berkeley.edu/ bhhall/ papers/HallVopel97.pdf>.

Hamel, G. (2011). Management Innovation Exchange. Retrieved March 10, 2012, from<http://www.managementexchange.com/ about-the-mix $>$.

Haybyrne, J. (2002, January). Cynicism Undermines Corporate Culture. South China Morning Post. HBR.org, (2012).Books, cases, articles and more. Retrieved June 10, 2012, from<http://hbr.org/product/thecreative-conspiracy-the-new-rules-of-breakthro/an/10617-HBKENG?Ntt=Collaboration $>$.

Hess, E. D. (2012). Creating an Innovation Culture: Accepting Failure is Necessary. Retrieved June 10, 2012, from <http://www.forbes.com/sites/darden/2012/06/20/creating-an-innovation-cultureaccepting-failure-is-necessary/ Forbes.com>.

Hewlett, S. (2011).Just Wanna Have Fun (and Flexibility).Retrieved June 10, 2012, from <http://blogs.hbr.org/hbr /hewlett/2011/06/ys_just_wanna_have_fun_--_and.html>.

Hussain, M. F., \&Illyas, S. (2011). Environment for innovation: gaining competitive advantage. African Journal of Business Management, 5(4), 1232-1235.

Ibarra, H.,\& Hansen, M. T. (2010, June). Are you a collaborative leader. HBR South Asia, 61-62.

IBM (2010).IBM Research: Innovation as a business model. Retrieved June 10, 2012, from

$<$ http://www.ibm.com >.

IBM (2010, October).Global Location trends.IBM Global Business Services.

ICTA (2012).Retrieved March 10, 2012, from<http:// www.icta.lk >. 
Jassawalla, A.R., \& Sashittal, H.C. (2002). Cultures that support product-innovation processes. Academy of Management Executive, 16(3), 42-54.

Lievens, F., \& Anseel, F. (2004).Confirmatory factor analysis and invariance of an organisational citizenship behaviour measure across samples in a Dutch-speaking context. Journal of Occupational and Organisational Psychology, 77(3), 299-306.

Malhotra, N.K., \& Birks, D.F. (2003).Marketing Research: An Applied Orientation.( $2^{\text {nd }}$ ed.). Pearson Education Limited.

Malhotra, N. K. (2004). Marketing research: An applied Orientation ( $4^{\text {th }}$ ed.). Upper Saddle River, NJ: Prentice Hall.

Malhotra, N.K. (2010). Marketing Research: An Applied Orientation. (6 $6^{\text {th }}$ ed.).Upper Saddle River, NJ: Prentice Hall.

Malhotra, N.K. (2011). Basic Marketing Research: Integration of Social Media. (4 ${ }^{\text {th }}$ ed.). Upper Saddle River, NJ: Prentice Hall.

Martins, E.C., \& Terblanche, F. (2003). Building organisational culture that stimulates creativity and innovation. European Journal of Innovation Management, 6(1), 64-74.

McShane, S., \&Von Glinow, M. (2005). Organisational behaviour. ( $3^{\text {rd }}$ ed.).Tata McGraw Hill.

Mindtools(2012).Management by Objectives.Retrieved March 10, 2012, from <http://www.mindtools.com/pages/ article/newTMM_94.htm>.

Naicker, N. (2008). Organisational Culture and Employee Commitment: A Case Study. Durban University of Technology.

Noor, K. M. B., \& Dola, K. (2012). Leveraging Training to Maximizing Employees Performance and Potential Benefits. Business and Management Review, 1(11), 19-26.

Rehman, R. R. (2009). Impact of Job Analysis on Job Performance. National University Of Modern Languages, Islamabad.

Sekeran, U. (2003). Research Methods for Business: A skill building approach. (5 ${ }^{\text {th }}$ ed.). Wiley, India. Sharkie, R. (2009). Trust in leadership is vital for employee performance. Management Research News, 32(5), 491-498.

Sinha, J. B. P. (2009). Culture and Organisational Behaviour. SAGE Publications Ltd.

SLASSCOM (2012).Retrieved March 10, 2012, from 〈http:/www.slasscom.lk>.

Sonnentag, S., \&Fresse, M. (2002).Performance Concepts and Performance Theory.Oxford: John Wiley \& Sons Ltd.

Stathakopoulos, V. (1998).Enhancing the performance of marketing managers: Aligning strategy, structure and evaluation systems, European Journal of Marketing, 32(5), 536-558.

Steelcase (2004). How collaborative workspaces nurture innovation. Retrieved March 10, 2012, from <www.steelcase.com>.

Sutton, R. I. (2001). Weird rules of creativity. Harvard Business Review, 79(8), 94-103.

Tidd, J., Bessant, J. \& Pavitt, K. (2005).Managing Innovation: Integrating Technological, Market and Organisational Change.( $3^{\text {rd }}$ ed.). Oxford: John Wiley \& Sons Ltd. 